\title{
Wildfire and fire mosaic effects on bird species richness and community composition in south-western Australia
}

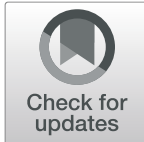

\author{
Allan J. Wills ${ }^{*}$ D, Graeme Liddelow and Verna Tunsell
}

\begin{abstract}
Background: A fire management strategy of deliberate patch-mosaic burning (PMB) is postulated to promote biodiversity by providing a range of habitat patches with different fire histories, habitat qualities, and vegetation ages at a given scale. We investigated the response of avian fauna to fire, particularly species richness and community composition, in a landscape composed of a diversity of vegetation ages including long-unburned refuges (age 26 years), compared with a landscape of uniform vegetation ages recovering from an extensive and intense fire.

Results: There was no effect of heterogeneity in vegetation age on species richness at whole forest management block (about $6000 \mathrm{ha}$ ), or local (2 ha) scales. There were different responses of particular species to vegetation age. Nine species showed responses to vegetation age at local (2 ha) scales, which is presumably a surrogate for availability of key resources and which changes over time. Australian Pipit (Anthus australis Vieillot, 1818) were absent from swamp vegetation $<3.5$ years old, while Spotted Pardalote (Pardalotus punctatus Shaw \& Nodder, 1792) were only found in forest vegetation $<3.5$ years old. Year-to-year changes in local assemblages were detected after removing the effect of time since fire. There was no difference in effect of the two fire regimes on assemblage composition or feeding-guild structure.

Conclusions: Mosaics of different vegetation ages had no net benefit for biodiversity, as measured by species richness and assemblage composition, at the forest block management unit scale. Different responses to vegetation age among bird species did not lead to increased bird richness at the scale of forest management block. A potential advantage of mosaics in conservation of avian biodiversity is through preservation of patches of older vegetation ages in the landscape, compared to the periodic extensive loss of older vegetation ages in wildfires. However, the absence of large-scale effects of vegetation age on bird species richness, the tendency for birds to specialize to fuel ages $>5.5$ years in the landscape studied, and indications of flexible responses of some species at landscape scales allows some flexibility in fuel management strategies and the scale at which they are applied with respect to avifauna.
\end{abstract}

Keywords: feeding, growth stage, guilds, jarrah, nesting, pyrodiversity

\footnotetext{
* Correspondence: Allan.Wills@dbca.wa.gov.au

Department of Biodiversity, Conservation and Attractions, Manjimup, Western

Australia, Australia
} 


\section{Resumen}

Antecedentes: La estrategia de realizar deliberadamente quemas en parches y mosaicos (PMB), es postulada como promotora de la biodiversidad, al proveer un rango de parches de hábitats con diferentes historias de fuego, calidad de hábitat, y edades de vegetación a distintas escalas. Investigamos la respuesta de la fauna aviar al fuego, particularmente la riqueza de especies y la composición de la comunidad, en un paisaje compuesto por una diversidad de edades de la vegetación incluyendo refugios sin quemar por largo tiempo (26 años), comparado con un paisaje de vegetación de edad uniforme recuperándose de un fuego extenso e intenso.

Resultados: No hubo efectos de la heterogeneidad en la edad de la vegetación sobre la riqueza de especies a nivel de todo el block de manejo forestal (alrededor de $6000 \mathrm{ha}$ ), o a escala local (2 ha). Hubo diferentes respuestas de especies particulares a la edad de la vegetación. Nueve especies mostraron respuestas a la edad de la vegetación a escala local (2 ha), lo que es presumiblemente un sucedáneo para disponer de recursos clave y que cambian en el tiempo. El bisbita australiano (Anthus australis Vieillot, 1818), estuvo ausente de la vegetación inundable (vegas o mallines) menores de 3,5 años de edad, mientras que el pardalote moteado (Pardalotus punctatus Shaw \& Nodder, 1792) fue encontrado solo en vegetación de bosques que tenía menos de 3,5 años de edad. Año a año, los cambios en los ensambles de aves locales fueron detectados cuando se removió en efecto desde el evento de fuego. No hubo diferencias en efectos entre los dos regímenes de fuego en la composición de los ensambles ni en la estructura de la distribución de la alimentación.

Conclusiones: Los mosaicos de diferentes edades de la vegetación no tuvieron un beneficio neto para la diversidad, medida como riqueza de especies y la composición del ensamble de aves a la escala de unidad del block de manejo forestal. Las diferentes respuestas a la edad de la vegetación entre las especies de aves no llevaron a un aumento en la riqueza de aves a la escala de block de manejo forestal. Una ventaja potencial de los mosaicos en la conservación de la biodiversidad de aves es a través de la preservación de parches de vegetación más antigua en el paisaje, comparada con la perdida periódica de la vegetación por incendios. Sin embargo, la ausencia de efectos de gran escala de la edad de la vegetación sobre la riqueza de especies de aves, la tendencia de las aves a especializarse en combustibles mayores a los 5,5 años en el paisaje estudiado, y la indicación de las respuestas flexibles de algunas especies a escala de paisaje, permiten cierta flexibilidad en las estrategias del manejo de los combustibles a la escala en que son aplicados con respecto a la avifauna.

\section{Background}

A goal of managers of fire in biological conservation areas is to maintain the capacity of managed units of land to sustain biodiversity and to minimize the extinction risk of individual species (Department of Parks and Wildlife 2017). A fire management strategy of deliberate patch-mosaic burning (PMB) was postulated to promote biodiversity by providing a range of habitat patches with different fire histories, habitat qualities, and seral stages at a given scale (Parr and Andersen 2006; Burrows 2008).

PMB theory has its origin in the mechanism of species coexistence described by Hutchinson (1953), whereby catastrophic events created empty patches ("biotopes"). Before dominant species eliminated weaker competing species, these weaker species could colonize and occupy the new patches. The consequences to biological diversity of the scale and frequency of catastrophic events are outlined by the Intermediate Disturbance Hypothesis (Connell 1978). According to this hypothesis, highest diversity is maintained at intermediate scales of disturbance. Considering disturbance frequency, where there is frequent disturbance, only those organisms capable of dispersing, colonizing, and reproducing within the disturbance interval will flourish. As the interval increases, diversity increases as more species are able to colonize and reproduce. At longer intervals, diversity decreases as competition between species becomes important, and certain species dominate or competitively exclude other species. Species richness is positively related to increasing spatial heterogeneity in habitat through the effects of amount, complexity, and variety of different habitats. Species richness is dependent on the provision of a variety of suitable shelter and refuges for species (Stein et al. 2014). Considering fire as a disturbance leading to habitat diversity for birds, the different requirements of different species are met by shifts and differences in the available quantity and range of required resources across seral stages after fire (Pons and Clavero 2010; Swan et al. 2018). Unburned patches also provide refuges during and after fire, retain propagule sources, and provide stepping stones for recolonization of burned areas after fire (Robinson et al. 2013; Sitters et al. 2015).

In general terms, the responses of bird species to fire are to severity and extent of fire (Barton et al. 2014; Lindenmayer et al. 2014; Berry et al. 2015b); the timing 
of fire in relation to vegetation succession, and structural and floral maturation processes (Pons and Clavero 2010; Watson et al. 2012b; Chalmandrier et al. 2013); and the spatial arrangement and contrast of vegetation ages in landscapes (Sitters et al. 2015; Sitters et al. 2016). Thus, the passage of time and recurrence of fire render mosaics of different vegetation ages as dynamic entities, and species diversity and community composition responses to them are also likely to be dynamic (e.g., Tingley et al. 2016).

The premise that mosaics of vegetation ages might lessen the extent and severity of unplanned fires while promoting biodiversity prompted the Department of Conservation and Land Management in Western Australia to investigate the feasibility of employing frequent applications of fire to construct a fine-scale, vegetation age mosaic across an entire forest block of several thousand hectares, and to examine effects on particular taxa, including avifauna (Burrows and Wardell-Johnson 2004).

This study investigated the response of avian fauna to fire, particularly species richness and community composition, in a landscape composed of a diversity of vegetation ages, including vegetation ages from unburned patches to 26 years, compared with one of extensive uniform vegetation ages (ages 1.5 and 9.5 years) recovering from an intense fire. We considered variation in species richness and community composition with time since last fire, and across land systems that are surrogates for broad vegetation units (Mattiske and Havel 1998, 2000). We tested the hypotheses that: (1) individual bird species are more common in particular post-fire vegetation ages; and (2) a fine-grain vegetation age mosaic induced by frequent introduction of fire under mild conditions offers an advantage, in terms of maintenance of, or increase in, species richness, over a vegetation age succession initiated by a single extensive fire event. We considered the effects of the different fire regimes on local species richness at 2-hectare sample points, as well as species richness at the scale of forest blocks across 6000 ha. We considered the implications of responses of individual bird species, feeding and nesting guilds, species richness, and assemblage composition to vegetation age and heterogeneity in vegetation age with respect to fire planning and management.

\section{Methods}

\section{Overview}

The study was conceived as a repeated measures factorial design of two forest blocks (subjected to different fire regimes) by three vegetation units by two replicates of sample points, which were sampled in 2004, 2008, and 2012. In 2008, sampling was completed only in one forest block, leading to incomplete replication over time and compromising the original design. The landscape was sampled with a stratified random design with repeated measures. Sample grids were stratified by forest block and vegetation unit, but there was a random element of placement within vegetation units. Our goals were to test for forest block, vegetation unit, and temporal effects on local ( $\sim 2 \mathrm{ha})$ species richness, assemblage composition, and feeding-guild composition. In addition, we wished to document changes in species richness at the forestblock scale (6000 ha) over time.

\section{Study area}

The study was conducted at London and Surprise forest blocks, $30 \mathrm{~km}$ northeast of Walpole in south-western Australia (Fig. 1). Surprise forest block consists of two sub-blocks: Surprise East and Surprise West. The climate of the region is mediterranean with cool, wet winters and warm, dry summers (Gentilli 1989). Mean annual rainfall was $\sim 1100 \mathrm{~mm}$, predominantly over the winter months. Mean monthly temperatures ranged from $15{ }^{\circ} \mathrm{C}$ to $26.7^{\circ} \mathrm{C}$ (Bureau of Meteorology 2016).

The soils and landforms of the study area were derived from granitic gneiss material (Churchward et al. 1988). Landforms form a catena of well-drained ridge and hillslope units (named Collis and Lindesay, respectively) and poorly drained swampy slopes, plains, and drainage floors named Caldyanup (Churchward et al. 1988). Vegetation on the Collis and Lindesay landform units is composed of an open eucalypt (Eucalyptus spp. L'Hér.) forest to $30 \mathrm{~m}$ tall dominated by jarrah (Eucalyptus marginata Donn ex Sm.) and marri (Corymbia calophylla [Lindl.] K.D. Hill \& L.A.S. Johnson), and having a dense shrubby understory to $2 \mathrm{~m}$ tall (Mattiske and Havel 1998, 2000). A variety of vegetation is associated with the Caldyanup landform unit, ranging from sedgedominated seasonal wetlands to heathlands of myrtaceous shrubs to $2 \mathrm{~m}$ tall.

\section{Fire treatments}

Surprise and London forest blocks differed in the fire regimes imposed on them. London block, an area of $\sim 5000$ ha, was burned prior to the study by a lowintensity fire in spring 1997. Further fire was introduced into London block: prescribed fire in spring 2002, wildfire in summer 2003, prescribed fire in autumn 2005, prescribed fire in autumn 2006, and prescribed fire in spring 2008. Introducing these fires was an attempt to create a fine-scale mosaic of small patches of vegetation at different ages since last fire (seral, or growth stages). By 2012, there were patches of vegetation from a few to several hundred hectares ranging from relatively recently burned to long unburned (Burrows and Middleton 2016). Heterogeneity 


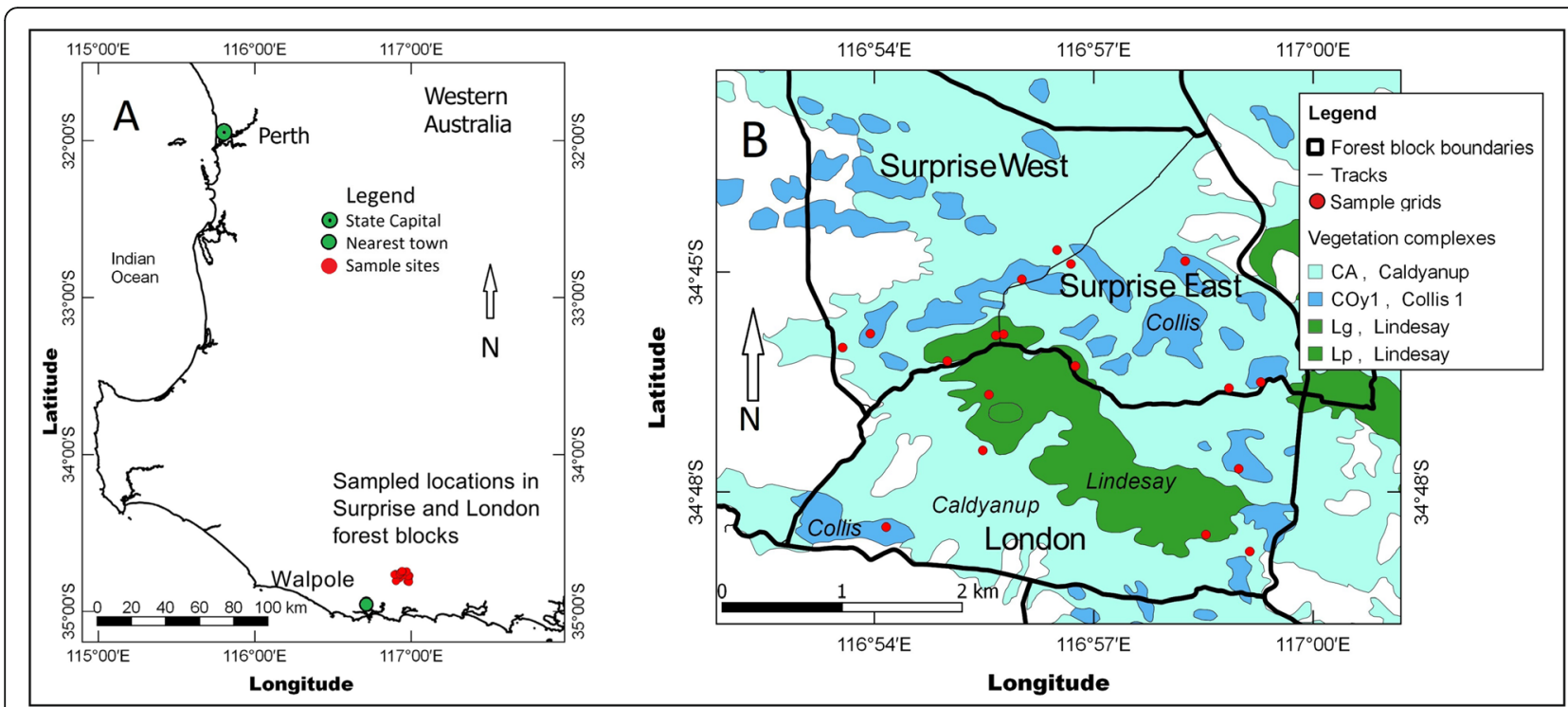

Fig. 1 Location of the study area and sample points on London and Surprise West forest blocks in south-western Australia. (A) Overview map showing location of sites in relation to nearest town and the Western Australian Capital city. (B) Location of sample points in Surprise and London forest blocks in south-western Australia sampled in 2004, 2008, and 2012. Access track dividing Surprise West from Surprise East sub-blocks is shown as Tracks in legend. Vegetation complexes are those of Mattiske and Havel $(1998,2000)$ and abbreviated names for complexes are as per those authors. For simplicity, Lindesay complexes Lg and Lp are shaded the same green and referred to as Lindesay in Methods. Collis 1 is referred to as Collis in the Methods. Sample points established in Surprise East forest block were not considered in this study

in vegetation ages occurred at scales within sample points (meters to tens of meters) and between sample points (hundreds of meters to kilometers) (Table 1). Surprise forest block ( 6700 ha), which adjoins London forest block to the north, was burned in one single fire event by an intense wildfire in March 2003 (Wittkuhn and Hamilton 2010). Forest blocks to the west, north, and east were consumed in the same fire. The 2003 fire was intense enough to cause spalling of exposed granite and complete combustion of crown foliage.

\section{Sample design}

A network consisting of 12 permanently marked sample points was established in 2004 in the three major land systems described above in both London (six sample points, two replicates of each vegetation unit) and Surprise West forest blocks (six sample points, two replicates of each vegetation unit) (Table 1). The six points on London were sampled in 2008 and 2012. No sample points were sampled in Surprise West in 2008, but sample points in Surprise West were sampled in 2012 (Table 1). Later than

Table 1 Vegetation units (Collis, Lindesay, or Caldyanup) and time since fire (years) up to $100 \mathrm{~m}$ from sample points on London and Surprise forest blocks in south-western Australia sampled for birds in spring of 2004, 2008, and 2012. Times since fire of multiple-age sample points are in parentheses; single-age sample points contain only one value (boldface) within parentheses. The predominant time since fire within multiple-age sample points used in analyses are in boldface. There are up to three vegetation ages (three ages within a set of parentheses) at a sample point

\begin{tabular}{|c|c|c|c|}
\hline \multirow[b]{2}{*}{ Forest block } & \multicolumn{3}{|c|}{ Time since fire on sample point (yr) } \\
\hline & Sampled Dec 2004 & Sampled Sep 2008 & Sampled Nov 2012 \\
\hline \multicolumn{4}{|c|}{ London forest block (mosaics of single-age and multiple vegetation-age sample points) } \\
\hline Collis (2 sample points) & $(18,2) ;(18,2)$ & $(22,6.5, \mathbf{3}) ;(\mathbf{3})$ & $(26,6,4.5) ;(6)$ \\
\hline Lindesay (2 sample points) & $(\mathbf{2}) ;(\mathbf{2})$ & $(22, \mathbf{3}) ;(\mathbf{3})$ & $(26,6,4.5) ;(6)$ \\
\hline Caldyanup (2 sample points) & $(\mathbf{2}) ;(\mathbf{2})$ & $(6.5) ;(6.5)$ & $(4.5) ;(4.5)$ \\
\hline \multicolumn{4}{|c|}{ Surprise West forest block (single-age sample points) } \\
\hline Collis (2 sample points) & $(1.5) ;(1.5)$ & No samples & $(9.5) ;(9.5)$ \\
\hline Lindesay (2 sample points) & $(1.5) ;(1.5)$ & No samples & $(9.5) ;(9.5)$ \\
\hline Caldyanup (2 sample points) & $(1.5) ;(1.5)$ & No samples & $(9.5) ;(9.5)$ \\
\hline
\end{tabular}


2014, other planned fire treatment overlaid the mosaic of ages on London forest block, ending the process of maintaining the fine-grain mosaic.

\section{Bird survey method}

Transect and area search methods are the two most widely used procedures for survey of birds in Australia (Pyke and Recher 1983). The point-count (Abbott et al. 2009), a variation on the transect count, was used due to the dense vegetation of the kind encountered on Collis and Lindesay units. The same experienced observer made each count and five counts were carried out in each sample point on consecutive days during each census period. Following a one-minute rest on arrival at the sample point, each bird seen or heard during a fiveminute interval at each point was counted and the horizontal distance to its location when first detected was estimated within one of six distance categories ( 0 to $5 \mathrm{~m}, 5$ to $10 \mathrm{~m}, 10$ to $20 \mathrm{~m}, 20$ to $30 \mathrm{~m}, 30$ to $60 \mathrm{~m}$, over $60 \mathrm{~m}$ ). Thus, there were 25 minutes of observation over $\sim 2$ ha around each sample point. The survey technique is certain to suffer the shortcomings of incomplete sampling, due firstly to limited sampling time as identified by Loyn (1986), and also to that associated with repeated transects identified by Watson (2004). We made no tests or corrections ( $c f$. Wintle et al. 2004) for potential differences in detectability between species. However, we attempted to sample all points on the same morning, within the constraints of the number of points and travel time between them. All counts were carried out in spring (Table 1) within four hours of sunrise, and the time of detection recorded as minutes after sunrise. Conditions of wind speed $>10 \mathrm{~km} \mathrm{hr}^{-1}$ and rain were avoided. Our intention was to minimize the effects of variability in sampling conditions on the detection of birds (Ellis and Taylor 2018), while allowing an exploration of forest block, vegetation, and temporal effects on bird richness and assemblage compositions. Thus, richness and abundances recorded were an index of richness and abundance rather than an absolute measure (Gregory et al. 2004). Avian nomenclature follows that described by Johnstone and Darnell (2018) (Additional file 1).

\section{Analysis \\ Hypothesis: Fire regime, or vegetation unit, or time since fire affect species richness at local or forest-block scales}

There are many measures of biodiversity (Heip et al. 1998), but the meaning and utility of the concept of diversity as expressed by some of these measures based on entropy formulae were questioned by Hurlbert (1971). It has been argued that reporting a spectrum of measures gives a more informed view of diversity responses to anthropogenic factors (Morris et al. 2014). For simplicity we opted for species richness (S) at sample point $\left(\mathrm{S}_{\text {POINT }}\right)$ and forest block $\left(\mathrm{S}_{\text {BLOCK }}\right)$ scales and separately considered community compositions (assemblages and abundances of species within assemblages). Data used to calculate $S_{\text {POINT }}$ for each year were species occurrences on London mosaics including points sampled in 2004, 2008, and 2012, and Surprise West age $1.5 \mathrm{yr}$ and age 9.5 yr. Due to the incomplete replication in 2008, and the small sample sizes, we relaxed the analytical design to conduct Kruskal-Wallis analyses (Corder and Foreman 2009) on $S_{\text {POINT }}$ values as follows: five "blocks" of these data corresponding to two forest blocks and their years sampled, of three vegetation units with their two replicate sample points, were subjected to a 1-way analysis comparing "blocks." Similarly, a 1-way analysis comparing vegetation units was conducted. The $\chi^{2}$ approximation was used to ascertain significance at $\alpha=0.05$ with number of groups minus one degree of freedom.

\section{Hypothesis: Individual species are more abundant at particular vegetation ages}

At least some species were expected to be more common in particular vegetation ages after fire. To determine vegetation age effects, we compared abundance of each species per sample point when paired observations within sample points from youngest vegetation (age $<3.5$ years) and oldest vegetation (age $>5.5$ years) were available from 2004, 2008, and 2012 data. Differences in raw abundance were tested with Wilcoxon pairedsample tests (Sokal and Rohlf 1981). Potential patch size and edge effects were unavoidable due to the necessity to combine London and Surprise West data for all vegetation units to provide a sufficient number of pairs. Using the same data, we identified species with exclusive vegetation unit preferences (Caldyanup or forest) and tested for age preferences using occurrence of samples that encountered particular species. We constructed contingency $(2 \times 2)$ tables describing numbers of samples by presence and absence, and in each of the youngest vegetation age $(<3.5$ years $)$ and oldest vegetation age ( $>5.5$ years) class and tested for independence between vegetation age and occurrence using Fisher Exact tests (Sokal and Rohlf 1981).

\section{Hypothesis: Particular feeding or nesting strategies are more common at particular vegetation ages}

Different species have different ecological requirements in terms of what they feed upon, where they feed, and where they nest. Different ecological requirements might be expected at different vegetation ages after fire. To determine the association between ecological requirements and vegetation ages after fire, 
we derived feeding and nesting strategies for each species from Abbott (1999) and Birdlife Australia (2018). Feeding strategies considered were: omnivore, carrion scavenger, vertebrate predator, insectivore general, insectivore ground, insectivore foliage, insectivore trunk or bark, insectivore aerial, nectar feeder, fruit eater, seed eater, and cambium feeder. Many species have multiple feeding strategies. Nesting location categories were: ground, understory, mid story, and overstory.

For each species we calculated the $\log _{10}$-transformed abundances in each sample and calculated mean difference between pairs of observations taken 1.5 and 9.5 years after fire. We calculated mean differences using only pairs of data for which the species were observed in one or both samples of the pair. We used the means to assign species as increasing in abundance, or decreasing in abundance between 1.5 and 9.5 years after fire. We tested for independence between apparent vegetation age preferences and feeding strategies, and apparent age preferences and nesting strategies, using Fisher Exact tests on numbers of species in categories in a similar manner to that described above. We confined comparisons to the Surprise West sample points to avoid potential patch size effects inherent in the London mosaic sample points.

\section{Hypothesis: Fire regime, vegetation unit, or time since fire affect feeding the guild composition of bird assemblages}

We derived a matrix of feeding strategies by species from the above feeding strategies. We obtained a species similarity matrix using Gower's coefficient (Clarke and Gorley 2006). Feeding guilds were delineated from this similarity matrix using a complete linkage CLUSTER analysis with SIMPROF tests (Clarke and Gorley 2006; Both et al. 2011). Eighteen entities were identified. After combining two categories of nectar feeders, two categories of foliage insectivores, and two categories of fruit and seed feeders, we used 13 guild categories for further analysis (Additional file 2). We summed abundances within these 13 guild categories for each sample point. Feeding-guild compositional similarities between sample points, according to vegetation age and vegetation type on London sample points from 2004 and 2012, and Surprise West sample points from 2004 and 2012 (see Table 1 ), were visually presented in a non-metric Multidimensional Scaling (nMDS) ordination derived from BrayCurtis dissimilarities between sample points (Clarke and Gorley 2006). Data used were $\log _{10}$ (guild abundance +1) on London 2004 and 2012, and Surprise West 2004 and 2012. We used permutational Multivariate Analysis of Variance (PerMANOVA; Anderson 2017) on the same Bray-Curtis dissimilarity matrix to examine vegetation age, forest block, vegetation, and year of measurement effects on similarities in feeding-guild composition between sample points. The covariate "years since fire" was fitted first. The age of greatest area was used when there were multiple ages on sample points (oldest ages were usually of smallest area after multiple fires at sample points). Type I sums of squares were used and restricted permutation of raw data with 9999 permutations allowed.

\section{Hypothesis: Fire regime, vegetation unit, or time since fire affect bird community composition}

Relative avian community compositional similarities between sample points, according to vegetation age and vegetation type on London sample points from 2004 and 2012 and Surprise West sample points from 2004 and 2012 (Table 1), were visually presented in an (nMDS) ordination derived from Bray-Curtis dissimilarity between measurement sample points using species $\log _{10}$ (species abundance +1 ). We then used PerMANOVA to examine years since fire, forest block, vegetation, and year of measurement effects on Bray-Curtis dissimilarity between sample points. The covariate "years since fire" was fitted first, as above. Type I sums of squares were used and restricted permutation of raw data with 9999 permutations allowed. Data used were $\log _{10}$ (species abundance +1 ) on London sample points from 2004 and 2012, and Surprise West sample points from 2004 and 2012 (Table 1).

\section{Results}

Effects of vegetation and forest block on species richness At the 2-hectare scale, separate 1-way Kruskal-Wallis analyses (Sokal and Rohlf 1981) revealed no effects of vegetation unit or "block" (forest block, vegetation age and vegetation age heterogeneity, and sample year) on $\mathrm{S}_{\mathrm{POINT}}$ ranges and medians. Ranges and medians in $\mathrm{S}_{\text {POINT }}$ values were similar between vegetation units and between "Blocks" (Tables 2 and 3). Species richness was similar at whole forest-block scale for London block mosaics and Surprise West single vegetation ages (Table 3).

\section{Individual species responses to vegetation age}

Responses to vegetation age, regardless of vegetation type, were identified for individual species from their

Table 2 Species richness at sample-point scale ( SPINT $_{\text {PIt }}$ win vegetation units. Equivalent sampling intensity (10 samples) applies for each vegetation unit. Samples are from London, Surprise East, and Surprise West forest blocks northeast of Walpole, Western Australia, from 2004 and 2012

\begin{tabular}{lllll}
\hline Vegetation unit & Median S SOINT & S POINT range & Mean SOINT & SE \\
\hline Caldyanup & 16.0 & 11 to 22 & 16.0 & 1.1 \\
Lindesay & 18.5 & 15 to 20 & 18.2 & 0.5 \\
Collis & 19.0 & 12 to 22 & 18.3 & 1.1 \\
\hline
\end{tabular}


Table 3 Species richness at sample-point scale ( $S_{\text {POINT }}$ ) within forest blocks and total richness at whole forest-block scale ( $\left.S_{B L O C K}\right)$. Equivalent sampling intensity (six samples) applies for London and Surprise West forest blocks. Samples are from London and Surprise West forest blocks northeast of Walpole, Western Australia, from 2004, 2008, and 2012

\begin{tabular}{llllllll}
\hline Forest block & Vegetation age $(\mathrm{yr})$ & Sample year & Median SPOINT & SpOINT range & Mean SPOINT & SE & S BLOCK \\
\hline London & Mosaic & 2004 & 17.5 & 11 to 20 & 16.7 & 1.38 & 35 \\
London & Mosaic & 2008 & 18.0 & 11 to 22 & 17.5 & 1.57 & 33 \\
London & Mosaic & 2012 & 18.5 & 16 to 22 & 18.8 & 34 \\
Surprise West & 1.5 & 2004 & 16.0 & 12 to 19 & 15.7 & 1.23 & 35 \\
Surprise West & 9.5 & 2012 & 19.0 & 14 to 22 & 18.8 & 1.14 & 33 \\
\hline
\end{tabular}

abundances on ages $>5.5$ or $<3.5$ years. Of the 18 species encountered in enough samples to be testable using Wilcoxon paired-sample tests (Sokal and Rohlf 1981; Table 4), only three species showed responses to vegetation age using this method: Red Wattlebird preferred younger vegetation while Grey Fantail and Whitebrowed Scrubwren preferred older vegetation. Using presence-absence data, five species were responsive to vegetation age in Caldyanup or forest vegetation units (Table 5). Spotted Pardalote (Pardalotus punctatus Shaw \& Nodder, 1792) preferred forest units of young vegetation age. Western White-naped Honeyeater (Melithreptus chloropsis Gould, 1844) and Whitebreasted Robin (Eopsaltria georgiana Quoy \& Gaimard, 1830) preferred forest units of older age.
Brown Songlark (Megalurus cruralis Vigors and Horsfield, 1827) tended to prefer young ages in Caldyanup while Australian Pipit (Anthus australis Vieillot, 1818) tended to prefer older ages in Caldyanup. Tree Martin (Petrochelidon nigricans Vieillot, 1817) showed large differences in forest block-scale distribution according to vegetation age. They showed no response to vegetation age on Caldyanup sample points yet were absent from forest sample points $<3.5$ years after fire.

\section{Composition of feeding and nesting guilds on sample points}

The nMDS of sample points by feeding-guild composition (Fig. 2) revealed separation of Caldyanup sample points from forest sample points. There was no

Table 4 Species with responses to vegetation age as detected by Wilcoxon paired-sample tests on differences in abundance without regard to vegetation units. The ranges of vegetation ages are: Young $=1.5$ to 3 years, and Old $=6$ to 9.5 years. Probability of a smaller Wilcoxon T statistic (2-tail) $\leq 0.05$ indicated by an asterisk $(*), P>0.05$ indicated by ns. Dashes $(-)$ indicate no apparent vegetation age preference. Refer to Additional file 1 for species names. Samples are from London and Surprise West forest blocks northeast of Walpole, Western Australia, from 2004, 2008, and 2012

\begin{tabular}{|c|c|c|c|c|}
\hline Common name & Number of sample pairs & $\begin{array}{l}\text { Mean difference in abundance } \\
\text { (birds per sample point) }\end{array}$ & $P$ of smaller $T$ & Vegetation age preference \\
\hline Tree Martin & 7 & 5.5 & ns & - \\
\hline Baudin's Cockatoo & 10 & 4.8 & ns & - \\
\hline Red Wattlebird & 8 & 2.0 & * & Young \\
\hline Western Rosella & 10 & 1.6 & ns & - \\
\hline Western Gerygone & 7 & 1.4 & ns & - \\
\hline Australian Ringneck & 7 & 0.9 & ns & - \\
\hline Western Spinebill & 10 & 0.3 & ns & - \\
\hline Grey Currawong & 7 & -0.1 & ns & - \\
\hline Western Golden Whistler & 10 & -0.4 & ns & - \\
\hline Laughing Kookaburra & 10 & -0.5 & ns & - \\
\hline Australian Raven & 8 & -0.5 & ns & - \\
\hline Black-faced Cuckoo-shrike & 10 & -0.6 & ns & - \\
\hline Striated Pardalote & 8 & -0.6 & ns & - \\
\hline Fan-tailed Cuckoo & 7 & -0.9 & ns & - \\
\hline Horsfield's Bronze-Cuckoo & 7 & -1.0 & ns & - \\
\hline Grey Fantail & 9 & -1.3 & * & Old \\
\hline Inland Thornbill & 10 & -1.5 & ns & - \\
\hline White-browed Scrubwren & 7 & -4.1 & * & Old \\
\hline
\end{tabular}


Table 5 Species with preferences for particular vegetation ages in vegetation types. Young vegetation (Young) ranges from 1.5 to 3 years old, while older vegetation (Old) ranges from 6 to 9.5 years old. Total number of samples in Caldyanup = 4: total number of samples in forest units $=6$. Samples are from London, Surprise East, and Surprise West forest blocks northeast of Walpole, Western Australia, from 2004, 2008, and 2012

\begin{tabular}{|c|c|c|c|c|}
\hline Common name & $\begin{array}{l}\text { Young vegetation } \\
\text { (count of samples) }\end{array}$ & $\begin{array}{l}\text { Old vegetation } \\
\text { (count of samples) }\end{array}$ & Fisher Exact probability (1-tail) & Vegetation age preference \\
\hline \multicolumn{5}{|c|}{ Species preferring either young or old vegetation age and found only in forest (Collis or Lindesay) } \\
\hline Spotted Pardalote & 4 & 0 & 0.03 & Young \\
\hline Western White-naped Honeyeater & 1 & 5 & 0.04 & Old \\
\hline White-breasted Robin & 1 & 6 & 0.008 & Old \\
\hline \multicolumn{5}{|c|}{ Species with indications of preference (significant at $a=0.10$ ) for either young or older vegetation age and found only in Caldyanup } \\
\hline Brown Songlark & 3 & 0 & 0.07 & Young \\
\hline Australian Pipit & 0 & 3 & 0.07 & Old \\
\hline \multicolumn{5}{|c|}{ Species with contrasting preferences for vegetation age between Caldyanup and forest vegetation units } \\
\hline Tree Martin (Caldyanup) & 3 & 2 & 0.5 & No preference \\
\hline Tree Martin (forest) & 0 & 4 & 0.03 & Old \\
\hline
\end{tabular}

apparent separation of forest blocks. PerMANOVA with "years since fire" as a covariate revealed vegetation unit (Pseudo- $F_{2,12}=4.6751, P_{\text {perm }}=0.0001$ ), and sample year (Pseudo- $F_{1,12}=3.1369, P_{\text {perm }}=0.016$ ), but not "years since fire" (Pseudo- $F_{1,12}=2.1096, P_{\text {perm }}=0.09$ ), or age heterogeneity-forest block (Pseudo- $F_{1,12}=1.7165, P_{\text {perm }}=0.16$ ) effects on guild composition. Caldyanup had different composition compared to Collis $\left(t=2.5653, P_{\text {perm }}=0.0003\right)$ and Lindesay $\left(t=2.0432, P_{\text {perm }}=0.006\right)$, while Collis and Lindesay had similar compositions $\left(t=1.5029, P_{\text {perm }}=0.073\right)$.

Certain bird-feeding strategies favored either younger or older vegetation ages after intense wildfire. Species more abundant at vegetation age $1.5 \mathrm{yr}$ had a greater number of feeding strategies than species more abundant at age $9.5 \mathrm{yr}$ (mean of $2.3 \mathrm{yr}$ versus mean of $1.5 \mathrm{yr}$, respectively; Mann-Whitney $U=285$, $\mathrm{df}=[20,19], P_{1-\text { tail }} \leq 0.005$ [Zar 1974]). Seed feeder and fruit eater strategies were more common among species that were more abundant at age $1.5 \mathrm{yr}$ than species more abundant at age $9.5 \mathrm{yr}$ (9 of 19 species versus 1 of 20 species, Fisher Exact [1-tail] $P=0.003$; 6 of 19 species versus 1 of 20 species, $P=0.04$, respectively). Note that most fruit feeders were also consuming the seeds within the fruit.

\section{Community composition}

The nMDS of assemblage composition revealed clear visual separation of Caldyanup from the forest vegetation units Collis and Lindesay, but weaker separation of the forest units from each other (Fig. 3). Clines in vegetation age were readily apparent in the arrangement of ages within vegetation units within the nMDS. Separation of sample years was also apparent while there was no apparent separation of forest blocks.
PerMANOVA with "years since fire" as a covariate revealed "years since fire" (Pseudo- $F_{1,12}=3.9275$, $\left.P_{\text {perm }}=0.0008\right)$, vegetation unit (Pseudo- $F_{2,12}=8.1974$, $\left.P_{\text {perm }}=0.0001\right)$, and sample year $\left(\right.$ Pseudo- $F_{1,12}=4.825$, $\left.P_{\text {perm }}=0.0001\right)$, but not age heterogeneity-forest block (Pseudo- $\left.F_{1,12}=1.613, P_{\text {perm }}=0.14\right)$ effects on bird community composition. Caldyanup had different composition compared to Collis $\left(t=3.485, P_{\text {perm }}=0.0001\right)$ and Lindesay $\left(t=3.051, P_{\text {perm }}=0.0001\right)$, while Collis and Lindesay had similar compositions $\left(t=1.399, P_{\text {perm }}=0.057\right)$.

\section{Discussion}

\section{Spatial scale and effects of fire heterogeneity on species richness}

Effects of fire heterogeneity on biodiversity need to be considered in the context of their spatial scale (Kotliar and Wiens 1990) and the unit of biodiversity measure (Morris et al. 2014). Species richness (S) at the sample point (2 ha, mean $\mathrm{S}_{\text {POINT }}$ of 15.7 to 18.8 species) and forest block (thousands of hectares, $\mathrm{S}_{\mathrm{BLOCK}}$ ranging from 33 to 35 species) scales observed in this study were consistent with, although less than, expectations from a meta-analysis by Abbott (1999). His Figure 14 predicted $S_{\text {POINT }}$ at $\sim 22$ and $\mathrm{S}_{\mathrm{BLOCK}}$ at $\sim 44$ species, but edge effects related to fragment size might have been important in his data.

Recovery in species richness after wildfire can be rapid (Christensen et al. 1985). Lack of significant difference in $\mathrm{S}_{\text {POINT }}$ on Surprise West forest block between 1.5 years and 9.5 years after fire, and similarity to $S_{\text {POINT }}$ on the mosaics that included older vegetation ages, suggest rapid recovery of species richness after wildfire. However, fire intensity and extent can have sustained effects on species richness at a local scale in eastern Australian Eucalyptus forest (Lindenmayer et al. 2014), while lack of response to 




Fig. 2 Non-metric multidimensional scaling (nMDS) ordination of sample points on London and Surprise West forest blocks in south-western Australia measured in 2004 and 2012 based on Bray-Curtis dissimilarity between sample points in feeding-guild compositions. The same ordination is coded for forest block in (A) and vegetation unit in (B). MDS1 and MDS2 are without units and are measures of relative similarity between data points. Numeric labels on data points are the predominant vegetation ages of the sample points

fire spatial structure in species richness at larger scales concurrent with responses in species richness at finer scales has been found elsewhere in Eucalyptus forest (Sitters et al. 2015).

There were no clear effects of spatial heterogeneity in terms of disposition of spatial structure of different vegetation ages since fire on $\mathrm{S}_{\text {POINT }}$ or $\mathrm{S}_{\text {BLOCK }}$ detected in the present study. We have some evidence of spatial variability in fire intensity within the same fire in the mosaic from satellite imagery of London forest block (see Ward et al. 2017: Figure 2), although fires on London block were generally milder in intensity than the wildfire on Surprise forest block. We cannot separate fire heterogeneity effects in terms of intensity from forest block-level effects within forest blocks. We presume heterogeneity in fire intensity would have been greater on London forest block. However, we detected no forest block effects in any of the analyses. Thus, the hypothesis that fire mosaics promote biodiversity as measured by bird species richness at these scales is not supported. At best, effects of mosaics on richness appear to be neutral in relation to a wildfire.

\section{Responses in bird community composition}

Particular bird species were more abundant in particular vegetation ages. However, a potential consequence of this-that there will be greater species richness at forestblock scale in a vegetation-age mosaic-was not supported. We found no effect of vegetation age heterogeneity on avian assemblage composition at forest-block scale once vegetation age effects were removed. That is, there were apparently neither effects of patch size on assemblage composition ( $c f$. Berry et al. 2015b) nor effects of juxtaposition of different patch ages ( $c f$. Sitters et al. 2015). Bird species are mobile in the landscape and exhibit preferences that vary across time according to 




Fig. 3 Non-metric multidimensional scaling (nMDS) ordination of main sample points on London and Surprise West forest blocks in southwestern Australia measured in 2004 and 2012 based on Bray-Curtis dissimilarity between sample points in community composition. The same ordination is coded for forest block in (A) and vegetation unit in (B). MDS1 and MDS2 are without units and are measures of relative similarity between data points. Numeric labels on data points are the predominant vegetation ages of the sample points

available resources within the landscape, resulting in changes in species assemblage composition. Species richness at local and forest-block scales is relatively stable.

There were vegetation age effects on community composition and there is evidence of species ecological traits driving these differences. "Years since fire" was a significant covariate affecting assemblage compositions on sample points. Swan et al. (2015) demonstrated that vegetation age is a surrogate for effects of underlying changes in availability of key resources with time since fire. While vegetation age is a surrogate for changes in resource distribution and abundance, rather than being a poor predictor of community composition in a heterogeneous landscape as predicted by Swan et al. (2015), "years since fire" as a covariate provided significant explanation of variation in bird community compositions in the Caldyanup, Collis, and Lindesay catenary landscape of the present study.
Vegetation units differed in their avian community compositions. Broad characteristics of feeding guilds were likely to contribute to these differences in bird community composition as the communities in Caldyanup and forest vegetation units had differing compositions of feeding guilds. Presence of canopy nesters in Caldyanup units that had no trees indicated utilization of multiple vegetation units by some species. Habitat specialization evidenced by some species such as Spotted Pardalote, a species sensitive to vegetation age boundaries and fire patchiness (Watson et al. 2012a), contributed to different assemblage compositions in each vegetation unit.

In south-west Western Australia, as in other ecosystems within mediterranean climates, fire plays a key role in modifying vegetation: as a selection process at millennial and geological time scales (Burrows and WardellJohnson 2003; Hopper 2003; He et al. 2011); in 
redistributing nutrient resources (Hingston et al. 1989); and through competition between plant species (Pekin et al. 2012a, 2012b). While bird species richness at both forest-block and sample-point scales was relatively unaffected by vegetation age, species composition apparently reflected the response of the bird community to understory regeneration, maturation, and senescence at local scales. These vegetation changes were a result of shifts in post-fire competition between the upper canopy and understory, and the senescence of seed-regenerating species (Pekin et al. 2012a, 2012b; Burrows et al. 2019).

\section{Responses of individual species}

Mosaics were advantageous at a 2 ha scale for those species with populations most affected by particular vegetation ages. These included species favored by young vegetation ages such as Brown Songlark in Caldyanup units, as well as those favored by older vegetation ages such as White-breasted Robin in forest units. Whitebreasted Robin is a species identified by others as possibly responsive to post-fire conditions ( $c f$. Wooller and Brooker 1980; Wooller and Calver 1988), and with cooperative breeding and persistent breeding territories (Russell and Brown 2004) that may be affected by fire.

Of note in the present study are the landscape-scale responses of Tree Martin, which apparently selected the landscape vegetation units it exploited depending on vegetation age. Additionally, the responses of Australian Pipit, more common at vegetation ages $>5.5$ years in the Caldyanup units, are contrary to expectations from observations elsewhere (Burbidge 2003). Local assemblage compositions also varied from year to year independent of changes in vegetation age.

These responses indicate that species responses to fire may be contextual. Some argue that individual species conform to one or other of a relatively narrow set of responses to time since fire when other relevant variables are accounted for (e.g., Smucker et al. 2005; Watson et al. 2012b). However, Burbidge (2003) reviewed Western Australian studies of several species that showed that species may respond differently to fire at different sites or under different fire conditions at the same site, possibly indicating sentient decisions and flexible behavior within limits in response to fire and the choices that fire creates in landscapes (Kaplan 2015; Serong and Lill 2016). Such responses may drive changes in assemblage composition within forest blocks and yet result in stable species richness at forest-block and local scales.

\section{Responses of feeding and nesting guilds}

The degree of specialization to particular food preferences may be a behavioral adaptation to post-fire conditions in fire-prone landscapes (Pausas and Parr 2018). For example, species with unspecialized and multiple feeding strategies are favored early post fire
(Prowse et al. 2017) when novel and windfall food sources may be more abundant and specialized sources temporarily scant (Woinarski 1999). In the present case, species more abundant 1.5 years after wildfire have on average more feeding strategies than species more abundant 9.5 years after fire. The observed population responses of fruit and seed feeders most likely indicate responses to flowering by about $70 \%$ of plant species in jarrah forest within 20 months of fire (Burrows and Wardell-Johnson 2003), and a pulse of fire-stimulated flowering, fruiting, and seed set by many understory species (Burrows and Wardell-Johnson 2003; Koch et al. 2010).

\section{Retention of older vegetation ages in the mosaic landscape}

Deliberate frequent introduction of fire led to the creation of a mosaic of vegetation of different ages. The mosaic formed through feedback loops under the influence of natural conditions such as differentials in moisture and topographic conditions (e.g., Wood et al. 2011), as well as the frequency of reintroduction of fire that led to spatial variability in the ability of fuels to carry fire, a characteristic also exploited by indigenous peoples to protect and maintain a variety of biotic and cultural assets (Kimmerer and Lake 2001; Russell-Smith et al. 2009). Patches of vegetation within the mosaic could be considered as refuges from active fire, as well as provide resources for recovery of bird populations after fire across the mosaic depending on post-fire vegetation age (Meddens et al. 2018). The mosaic included ephemeral and persistent refuges over the period of reintroduction of fire, which provided resources for species specialized to particular seral stages (Tables 4 and 5) or spatial scales in the disposition of these resources.

There is evidence that recolonization by bird species from ex-situ source populations is an important process in post-fire recovery (Mallee shrublands, Watson et al. 2012a; Mediterranean forest, garrigue, or maquis, Brotons et al. 2005). In the present study, we detected no ongoing loss of species richness 1.5 years after intense wildfire, implying rapid recolonization of the 6000 ha forest block from ex-situ sources, and similar in rapidity to recolonization of the mosaic forest block where there were unburned refuges. However, we did not control for edge effects in the positioning of sample points on the wildfire forest block, which may have led to apparently rapid recolonization in our results.

Relatively greater benefits of mosaics of any scale may be provided through retention of habitat as a source for recolonization of burned areas by fire-responsive species whose populations are greater in large continuous tracts of unburned vegetation at older ages, compared with provision of a variety of ages including young vegetation 
ages (Berry et al. 2015b). Sitters et al. (2015) suggested that the open understory conditions post fire were transient and uncommon in eucalypt forest with long fire return intervals, providing little or no selection pressure for specialization into that forest habitat. Elsewhere for Eucalyptus forest and woodlands and shrublands, others have argued that vegetation ages much older than 10 years should be favored vegetation age classes for birds in mosaics of different times since fire (Taylor et al. 2012; Di Stefano et al. 2013; Berry et al. 2015b; Kelly et al. 2015; Davis et al. 2016). Edge effects disappeared by six years after fire in the mallee shrubland study by Watson et al. (2012a). In montane Californian forests, mosaics of different times since fire take time to mature to support greatest bird diversity (Tingley et al. 2016). We suggest that the foregoing supports retention of vegetation ages later than about six years in mosaics of vegetation ages for the purposes of maximizing avian biodiversity in Collis and Lindesay jarrah forest.

A consequence of maintaining extensive areas of older vegetation ages in jarrah forest is that their fuel loads lend to predisposition for wildfires (Gould et al. 2007), which, when they inevitably occur, result in low spatial heterogeneity in time since fire and a period of extensive young ages within forest management blocks (e.g., Leonard et al. 2014). A drawback of mosaics of different vegetation ages as established in the present case is that patches of old age tend to be small and therefore potentially of less value for biodiversity conservation than large patches (Berry et al. 2015b). In addition, the distribution of vegetation ages is likely to be sensitive to the relative burn area of periodically reintroduced fire, potentially leading to relatively small areas of older vegetation ages at low (3 to $5 \% \mathrm{yr}^{-1}$ of total available area) relative burn areas (Connell et al. 2019).

\section{Implications of avian responsiveness to vegetation age management}

Responses of bird communities to vegetation growth stage (for which vegetation age is a surrogate) provide at least a theoretical possibility that growth stage optimization (GSO) modeling of vegetation growth stage dynamics and bird species responses can provide prescriptive goals for fire managers that potentially result in optimal biodiversity outcomes (Swan et al. 2015, Sitters et al. 2018: Swan et al. 2018). Modeled optimal growth stage mosaics have been demonstrated for bird communities in Eucalyptus forests of eastern Australia (Sitters et al. 2018; Swan et al. 2018). Such models consider habitat specialization and requirements of species and predict an optimal availability of stages and fire severity in the landscape that meets those requirements to maximize populations for the most species. The suite of preferences among species determines the bird community responses to the suite of stages available in the landscape, to their extent in the landscape, and to the spatial characteristics and arrangement of different vegetation age units (Di Stefano et al. 2013; Kelly et al. 2015; Sitters et al. 2018; Swan et al. 2018). Whereas the "humans as controlling engineers" narrative (e.g., Craig 2015, with respect to climate) underlies the methodology for GSO development and implementation, translation of modeled goals into outcomes remains vulnerable to the extent of knowledge, happenstance, and chance elements in human management of fire in the landscape (the counter narrative of nature as a "trickster," a source of surprises).

\section{Conclusions}

The fine-grain mosaics created in this study were not created to a prescribed set of growth stages. Rather, they were created according to the flammability of landscape in the context of frequent introduction of fire under mild conditions to create and maintain spatial heterogeneity in vegetation ages. Such a fire regime is likely to be more expensive in time and cost than the prescribed fires of forest-block scale currently implemented in jarrah forest. In addition, implementing the mosaic requires favorable fuel moisture and weather conditions, elements subject to incomplete knowledge and chance.

In weighing the benefits of the fine-grain mosaics created, the effects of fine-grain mosaics of different times since fire were expressed in the effects of vegetation age on populations of particular species at local ( 2 ha) scales. Bird species of management priority might benefit from mosaic-inducing fire regimes, depending on the ecological requirements of the species. There are limitations to successful implementation of fire mosaics with respect to priority species. Firstly, there is the consideration of conditions leading to the ephemeral versus persistent nature of fire refuges within a given location under global change (Berry et al. 2015a). Secondly, there is the need to sufficiently inform the presence, life history characteristics, and responses of the priority species in areas subject to these mosaics (Driscoll et al. 2010).

While there was support for differences among species in abundance according to vegetation ages, there was no net benefit of fire mosaics compared to a wildfire as measured by species richness and assemblage composition at local ( $2 \mathrm{ha}$ ) and forest management block (6000 ha) scales. The absence of large-scale effects of vegetation age on bird species richness, the tendency for birds to specialize to fuel ages $>5.5$ years in the landscape studied, and indications of flexible responses of some species at forest-block scales allows some flexibility in the return cycle of fuel management strategies and the scale at which they are applied with respect to the 
avifauna. The range of variation in the current prescribed fire regimes in jarrah forest and their scale of application (Burrows and McCaw 2013; McCaw 2013) do not appear inimical to the persistence of the suite of bird species encountered in the present study.

\section{Supplementary information}

Supplementary information accompanies this paper at https://doi.org/10. 1186/s42408-019-0065-5.

Additional file 1. Species recorded in 2004, 2008, and 2012 in forest blocks in south-western Australia. Mean abundances per sample point were derived from six sample points on each of London forest block vegetation-age mosaics and Surprise West forest block seral stages after fire. Note that each forest block is a landscape of Collis and Lindesay forest, and Caldyanup heath and sedge-land vegetation units. There was equivalent sampling effort on each forest block for each vegetation unit. Species are listed in the taxonomic sequence of Johnstone and Darnell (2018)

Additional file 2. Bird feeding guilds and their feeding strategies defined by CLUSTER analysis. Strategies marked with 1 were common to all members of the guild. Strategies marked with an asterisk $\left(^{*}\right)$ may be present. Strategies marked with 0 were not reported to be present in the guild. Samples are from London and Surprise West forest blocks northeast of Walpole, Western Australia, from 2004, 2008, and 2012.

\section{Acknowledgements}

We thank Frankland District staff for implementing the burns to generate the vegetation-age mosaic; and I. Abbott, L. McCaw, and two anonymous reviewers for patience, comments, and critique of earlier drafts.

\section{Authors' contributions}

GL conceived and designed the avian component of the study, collected field observation data, and critically reviewed the data analysis and manuscript for accuracy; $V T$ collated and verified the field data and maintains the database; and AW analyzed the data and drafted the manuscript. All authors read and approved the final manuscript.

\section{Funding}

The study was conducted with funding by the Western Australian Department of Biodiversity, Conservation and Attractions and its preceding organizational forms.

\section{Availability of data and materials}

The datasets used or analyzed during the current study are available from the corresponding author on reasonable request.

\section{Ethics approval and consent to participate}

Department of Biodiversity, Conservation and Attractions Animal Ethics Committee approval number is 2010/48 Burning for biodiversity: Walpole fine grain mosaic burning trial-fire-induced habitat mosaics in SW landscapes.

\section{Consent for publication}

Not applicable.

\section{Competing interests}

The authors declare that they have no competing interests.

Received: 21 March 2019 Accepted: 17 December 2019

Published online: 29 January 2020

\section{References}

Abbott, I. 1999. The avifauna of the forests of south-west Western Australia: changes in species composition, distribution, and abundance following anthropogenic disturbance. CALMScience Supplement 5: 1-176.

Abbott, I., G. Liddelow, C. Vellios, A. Mellican, and M. Williams. 2009. Monitoring bird populations after logging in forests of south-west Western Australia: an update from two long-term experimental research case studies. Conservation Science Western Australia 7: 301-347.

Anderson, M.J. 2017. Permutational multivariate analysis of variance (PERMANOVA). In Wiley StatsRef: Statistics Reference Online, ed. N. Balakrishnan, T. Colton, B. Everitt, W. Piegorsch, F. Ruggeri, and J.L. Teugels, 1-15. Hoboken: Wiley. https://doi.org/10.1002/9781118445112.stat07841.

Barton, P.S., K. Ikin, A.L. Smith, C. MacGregor, and D.B. Lindenmayer. 2014. Vegetation structure moderates the effect of fire on bird assemblages in a heterogeneous landscape. Landscape Ecology 29 (4): 703-714. https://doi.org/ 10.1007/s10980-014-0017-Z.

Berry, L.E., D.A. Driscoll, J.A. Stein, W. Blanchard, S.C. Banks, R.A. Bradstock, and D.B. Lindenmayer. 2015a. Identifying the location of fire refuges in wet forest ecosystems. Ecological Applications 25 (8): 2337-2348. https://doi.org/10 1890/14-1699.1

Berry, L.E., D.B. Lindenmayer, and D.A. Driscoll. 2015b. Large unburnt areas, not small unburnt patches, are needed to conserve avian diversity in fire-prone landscapes. Journal of Applied Ecology 52: 486-495. https://doi.org/10.1111/ 1365-2664.12387.

Birdlife Australia. 2018. Find a bird. http://www.birdlife.org.au/all-about-birds/ australias-birds/find-a-bird. Accessed 29 May 2018.

Both, C., S.Z. Cechin, A.S. Melo, and S.M. Hartz. 2011. What controls tadpole richness and guild composition in ponds in subtropical grasslands? Austral Ecology 36 (5): 530-536. https://doi.org/10.1111/j.1442-9993.2010.02183.x.

Brotons, L., P. Pons, and S. Herrando. 2005. Colonization of dynamic Mediterranean landscapes: where do birds come from after fire? Journal of Biogeography 32: 789-798. https://doi.org/10.1111/j.1365-2699.2004.01195.x.

Burbidge, A.H. 2003. Birds and fire in the mediterranean climate of south-west Western Australia. In Fire in ecosystems of south-west Western Australia: impacts and management, ed. I. Abbott and N. Burrows, 321-347. Leiden: Backhuys Publishers.

Bureau of Meteorology. 2016. Weather data online. http://www.bom.gov.au/ Accessed 12 Feb 2016

Burrows, N. 2008. Linking fire ecology and fire management in south-west Australian forest landscapes. Forest Ecology and Management 255: 2394-2406. https://doi.org/10.1016/j.foreco.2008.01.009.

Burrows, N.D., and L. McCaw. 2013. Prescribed burning in southwestern Australian forests. Frontiers in Ecology and the Environment 11 (s1): e25-e34. https://doi.org/10.1890/120356.

Burrows, N., and T. Middleton. 2016. Mechanisms enabling a fire sensitive plant to survive frequent fires in south-west Australian eucalypt forests. Fire Ecology 12 (1): 26-39. https://doi.org/10.4996/fireecology.1201026.

Burrows, N., B. Ward, A. Wills, M. Williams, and R. Cranfield. 2019. Fine-scale temporal turnover of jarrah forest understory vegetation assemblages is independent of fire regime. Fire Ecology 15 (1): 10. https://doi.org/10.1186/ s42408-019-0025-0.

Burrows, N.D., and G. Wardell-Johnson. 2003. Fire and plant interactions in forested ecosystems of south-west Western Australia. In: Fire in ecosystems of south-west Western Australia: impacts and management, ed. I. Abbott and N. Burrows, 225-268. Leiden: Backhuys Publishers.

Burrows, N.D., and G. Wardell-Johnson. 2004. Implementing fire mosaics to promote biodiversity and prevent severe wildfires in south-west Australian ecosystems. In Proceedings of the 11th annual AFAC conference and inaugural bushfire CRC conference, Bushfire CRC. Kensington: Western Australia Department of Conservation and Land Management.

Chalmandrier, L., G.F. Midgley, P. Barnard, and C. Sirami. 2013. Effects of time since fire on birds in a plant diversity hotspot. Acta Oecologica 49: 99-106. https://doi.org/10.1016/j.actao.2013.03.008.

Christensen, P.E.S., G. Wardell-Johnson, and P. Kimber. 1985. Birds and fire in southwestern forests. In: Birds of eucalypt forests and woodlands: ecology, conservation and management, ed. A. Keast, H.G. Recher, H. Ford, and D. Saunders, 291-299. Chipping Norton: Surrey Beatty and Sons.

Churchward, H.M., W.M. McArthur, P.L. Sewell, and G.A. Bartle. 1988. Landforms and soils of the south coast and hinterland W.A. Northcliffe to Many Peaks. CSIRO Water Resources Division Report. 88/1. Canberra: CSIRO.

Clarke, K.R., and R.N. Gorley. 2006. PRIMER v6: user manual/tutorial. Plymouth: Primer-E Ltd.

Connell, J.H. 1978. Diversity in tropical rain forests and coral reefs. Science 199 (4335): 1302-1310. https://doi.org/10.1126/science.199.4335.1302.

Connell, J., S.J. Watson, R.S. Taylor, S.C. Avitabile, N. Schedvin, K. Schneider, and M.F. Clarke. 2019. Future fire scenarios: predicting the effect of fire management strategies on the trajectory of high-quality habitat for 
threatened species. Biological Conservation 232: 131-141. https://doi.org/10. 1016/j.biocon.2019.02.004.

Corder, G.W., and D.I. Foreman. 2009. Nonparametric statistics for non-statisticians. Hoboken: Wiley. https://doi.org/10.1002/9781118165881.

Craig, R.K. 2015. Learning to live with the trickster: narrating climate change and the value of resilience thinking. Pace Environmental Law Review 33: 351-396.

Davis, R.A., T.S. Doherty, E.J. van Etten, J.Q. Radford, F. Holmes, C. Knuckey, and B.J. Davis. 2016. Conserving long unburnt vegetation is important for bird species, guilds and diversity. Biodiversity and Conservation 25 (13): 2709-2722. https://doi.org/10.1007/s10531-016-1196-5.

Department of Parks and Wildlife. 2017. Department of Parks and Wildlife 201617 annual report. https://www.dpaw.wa.gov.au/about-us/annual-report-andyearbook Accessed 13 June 2018.

Di Stefano, J., M.A. McCarthy, A. York, T.J. Duff, J. Slingo, and F. Christie. 2013. Defining vegetation age class distributions for multispecies conservation in fire-prone landscapes. Biological Conservation 166: 111-117. https://doi.org/ 10.1016/j.biocon.2013.06.022.

Driscoll, D.A., D.B. Lindenmayer, A.F. Bennett, M. Bode, R.A. Bradstock, G.J. Cary, M.F. Clarke, N. Dexter, R. Fensham, G. Friend, M. Gil, S. James, G. Kay, D.A. Keith, C. MacGregor, J. Russell-Smith, D. Salt, J.E.M. Watson, R.J. Williams, and A. York. 2010. Fire management for biodiversity conservation: key research questions and our capacity to answer them. Biological Conservation 143: 1928-1939. https://doi.org/10.1016/j.biocon.2010.05.026.

Ellis, M.V., and J.E. Taylor. 2018. Effects of weather, time of day, and survey effort on estimates of species richness in temperate woodlands. Emu-Austral Ornithology 118 (2): 183-192. https://doi.org/10.1080/01584197.2017.1396188.

Gentilli, J. 1989. Climate of the jarrah forest. In: The jarrah forest: a complex mediterranean ecosystem, ed. B. Dell, J.J. Havel, and N. Malajczuk, 23-40. Dordrecht: Kluwer Academic Publishers. https://doi.org/10.1007/978-94-0093111-4_3.

Gould, J.S., W.L. McCaw, N.P. Cheney, P.F. Ellis, and S. Matthews. 2007. Field guide-fuel assessment and fire behaviour prediction in dry eucalypt forest. Canberra and Perth: Ensis-CSIRO, and Department of Environment and Conservation.

Gregory, R.D., D.W. Gibbons, and P.F. Donald. 2004. Bird census and survey techniques. In: Bird ecology and conservation: a handbook of techniques (volume 1), ed. W.J. Sutherland, I. Newton, R.E. Green, and R. Green, 17-56. Oxford: Oxford University Press. https://doi.org/10.1093/acprof:oso/ 9780198520863.003.0002.

He, T., B.B. Lamont, and K.S. Downes. 2011. Banksia born to burn. New Phytologist 191: 184-196. https://doi.org/10.1111/j.1469-8137.2011.03663.x.

Heip, C.H., P.M. Herman, and K. Soetaert. 1998. Indices of diversity and evenness. Océanis 24 (4): 61-88.

Hingston, F.J., A.M. O'Connell, and T.S. Grove. 1989. Nutrient cycling in the jarrah forest. In: The jarrah forest: a complex mediterranean ecosystem, ed. B. Dell, J.J. Havel, and N. Malajczuk, 155-177. Dordrecht: Kluwer Academic Publishers. https://doi.org/10.1007/978-94-009-3111-4_11.

Hopper, S.D. 2003. An evolutionary perspective on south-west Western Australian landscapes, biodiversity and fire: a review and management implications. In: Fire in ecosystems of south-west Western Australia: impacts and management, ed. I. Abbott and N. Burrows, 9-35. Leiden: Backhuys Publishers.

Hurlbert, S.H. 1971. The nonconcept of species diversity: a critique and alternative parameters. Ecology 52 (4): 577-586. https://doi.org/10.2307/1934145.

Hutchinson, G.E. 1953. The concept of pattern in ecology. Proceedings of the Academy of Natural Sciences of Philadelphia 105: 1-12.

Johnstone, R.E., J.C. Darnell. 2018. Checklist of the birds of Western Australia, September 2018. http://museum.wa.gov.au/sites/default/files/Checklist\%20of\%2 OBirds\%20of\%20WA\%20-\%20April\%202018_0.pdf. Accessed 12 Jul 2019.

Kaplan, G. 2015. Bird minds: cognition and behaviour of Australian native birds. Canberra: CSIRO Publishing. https://doi.org/10.1071/9781486300198.

Kelly, L.T., A.F. Bennett, M.F. Clarke, and M.A. McCarthy. 2015. Optimal fire histories for biodiversity conservation. Conservation Biology 29 (2): 473-481. https://doi. org/10.1111/cobi.12384.

Kimmerer, R.W., and F.K. Lake. 2001. The role of indigenous burning in land management. Journal of Forestry 99 (11): 36-41. https:/doi.org/10.1093/jof/99.11.36.

Koch, J.M., A.M. Ruschmann, and T.K. Morald. 2010. Effect of time since burn on soil seedbanks in the jarrah forest of Western Australia. Australian Journal of Botany 57 (8): 647-660. https://doi.org/10.1071/BT09101.

Kotliar, N.B., and J.A. Wiens. 1990. Multiple scales of patchiness and patch structure: a hierarchical framework for the study of heterogeneity. Oikos 59: 253-260. https://doi.org/10.2307/3545542.
Leonard, S.W., A.F. Bennett, and M.F. Clarke. 2014. Determinants of the occurrence of unburnt forest patches: potential biotic refuges within a large, intense wildfire in south-eastern Australia. Forest Ecology and Management 314: 85-93. https://doi.org/10.1016/j.foreco.2013.11.036.

Lindenmayer, D.B., W. Blanchard, L. McBurney, D. Blair, S.C. Banks, D.A. Driscoll, A.L. Smith, and A.M. Gill. 2014. Complex responses of birds to landscape-level fire extent, fire severity and environmental drivers. Diversity and Distributions 20 (4): 467-477. https://doi.org/10.1111/ddi.12172.

Loyn, R.H. 1986. The 20 minute search—a simple method for counting forest birds. Corella 10: 58-60.

Mattiske, E.M., and J.J. Havel. 1998. Regional forest agreement vegetation complexes Pemberton Western Australia [cartographic material Pemberton-scale 1:250 000]. Como: Western Australia Department of Conservation and Land Management.

Mattiske, E.M., and J.J. Havel. 2000. Vegetation mapping in the south west of Western Australia. Perth: Western Australia Department of Conservation and Land Management.

McCaw, W.L. 2013. Managing forest fuels using prescribed fire: a perspective from southern Australia. Forest Ecology and Management 294: 217-224. https://doi. org/10.1016/j.foreco.2012.09.012.

Meddens, A.J., C.A. Kolden, J.A. Lutz, A.M. Smith, C.A. Cansler, J.T. Abatzoglou, G.W. Meigs, W.M. Downing, and M.A. Krawchuk. 2018. Fire refugia: what are they, and why do they matter for global change? BioScience 68 (12): 944954. https://doi.org/10.1093/biosci/biy103.

Morris, E.K., T. Caruso, F. Buscot, M. Fischer, C. Hancock, T.S. Maier, T. Meiners, C. Müller, E. Obermaier, D. Prati, and S.A. Socher. 2014. Choosing and using diversity indices: insights for ecological applications from the German Biodiversity Exploratories. Ecology and Evolution 4 (18): 3514-3524. https://doi. org/10.1002/ece3.1155.

Parr, C.L., and A.N. Andersen. 2006. Patch mosaic burning for biodiversity conservation: a critique of the pyrodiversity paradigm. Conservation Biology 20 (6): 1610-1619. https://doi.org/10.1111/j.1523-1739.2006.00492.x.

Pausas, J.G., and C.L. Parr. 2018. Towards an understanding of the evolutionary role of fire in animals. Evolutionary Ecology 32: 113-125. https://doi.org/10. 1007/s10682-018-9927-6.

Pekin, B.K., M.M. Boer, R.S. Wittkuhn, C. Macfarlane, and P.F. Grierson. 2012a. Plant diversity is linked to nutrient limitation of dominant species in a world biodiversity hotspot. Journal of Vegetation Science 23: 745-754. https://doi. org/10.1111/j.1654-1103.2012.01386.x.

Pekin, B.K., R.S. Wittkuhn, M.M. Boer, C. Macfarlane, and P.F. Grierson. $2012 \mathrm{~b}$. Response of plant species and life form diversity to variable fire histories and biomass in the jarrah forest of south-west Australia. Austral Ecology 37: 330338. https://doi.org/10.1111/j.1442-9993.2011.02280.x.

Pons, P., and M. Clavero. 2010. Bird responses to fire severity and time since fire in managed mountain rangelands. Animal Conservation 13 (3): 294-305 https://doi.org/10.1111/j.1469-1795.2009.00337.x.

Prowse, T.A., S.J. Collard, A. Blackwood, P.J. O'Connor, S. Delean, M. Barnes, P. Cassey, and H.P. Possingham. 2017. Prescribed burning impacts avian diversity and disadvantages woodland-specialist birds unless long-unburnt habitat is retained. Biological Conservation 215: 268-276. https://doi.org/10. 1016/.biocon.2017.09.005

Pyke, G., and H.F. Recher. 1983. Censusing Australian birds: a summary of procedures and a scheme for standardization of data presentation and storage. In: Methods of censusing birds in Australia. Proceedings of a symposium organised jointly by the zoology section of ANZAAS and the Western Australian Group of the Royal Australasian Ornithologists Union, ed. S.J.J. Davies, 55-63. Perth: Western Australian Department of Conservation and Environment.

Robinson, N.M., S.W. Leonard, E.G. Ritchie, M. Bassett, E.K. Chia, S. Buckingham, H. Gibb, A.F. Bennett, and M.F. Clarke. 2013. REVIEW: refuges for fauna in fireprone landscapes: their ecological function and importance. Journal of Applied Ecology 50 (6): 1321-1329. https://doi.org/10.1111/1365-2664.12153.

Russell, E.M., and M.N. Brown. 2004. Life history of the White-breasted Robin, Eopsaltria georgiana (Petroicidae), in south-western Australia. Australian Journal of Zoology 52 (2): 111-145. https://doi.org/10.1071/ZO03049.

Russell-Smith, J., P. Whitehead, and P. Cooke. 2009. Culture, ecology and economy of fire management in North Australian savannas: rekindling the Wurrk tradition. Canberra: CSIRO Publishing. https://doi.org/10.1071/ 9780643098299.

Serong, M., and A. Lill. 2016. Plasticity and stereotypy in avian foraging during secondary succession in temperate forests. Avian Biology Research 9 (3): 174194. https://doi.org/10.3184/175815516X14628979803437. 
Sitters, H., J. Di Stefano, F.J. Christie, P. Sunnucks, and A. York. 2015. Bird diversity increases after patchy prescribed fire: implications from a before-after control-impact study. International Journal of Wildland Fire 24 (5): 690-701. https://doi.org/10.1071/WF14123.

Sitters, H., J. Di Stefano, F. Christie, M. Swan, and A. York. 2016. Bird functional diversity decreases with time since disturbance: does patchy prescribed fire enhance ecosystem function? Ecological Applications 26 (1): 115-127. https:// doi.org/10.1890/14-1562.

Sitters, H., J. Di Stefano, T. Wills, M. Swan, and A. York. 2018. Survey design for precise fire management conservation targets. Ecological Applications 28 (1): 35-45. https://doi.org/10.1002/eap.1624.

Smucker, K.M., R.L. Hutto, and B.M. Steele. 2005. Changes in bird abundance after wildfire: importance of fire severity and time since fire. Ecological Applications 15: 1535-1549. https://doi.org/10.1890/04-1353.

Sokal, R.R., and F.J. Rohlf. 1981. Biometry. Second edition. New York: WH Freeman and Company.

Stein, A., K. Gerstner, and H. Kreft. 2014. Environmental heterogeneity as a universal driver of species richness across taxa, biomes and spatial scales. Ecology Letters 17 (7): 866-880. https://doi.org/10.1111/ele. 12277.

Swan, M. F. Christie, H. Sitters, A. York, and J. Di Stefano. 2015. Predicting faunal fire responses in heterogeneous landscapes: the role of habitat structure. Ecological Applications 25 (8): 2293-2305. https://doi.org/10.1890/14-1533.1.

Swan, M., H. Sitters, J. Cawson, T. Duff, Y. Wibisono, and A. York. 2018. Fire planning for multispecies conservation: integrating growth stage and fire severity. Forest Ecology and Management 415: 85-97. https://doi.org/10.1016/ j.foreco.2018.01.003

Taylor, R.S., S.J. Watson, D.G. Nimmo, L.T. Kelly, A.F. Bennett, and M.F. Clarke. 2012. Landscape-scale effects of fire on bird assemblages: does pyrodiversity beget biodiversity? Diversity and Distributions 18 (5): 519-529. https://doi.org/10. 1111/j.1472-4642.2011.00842.x.

Tingley, M.W., V. Ruiz-Gutiérrez, R.L. Wilkerson, C. Howell, and R.B. Siegel. 2016 Pyrodiversity promotes avian diversity over the decade following forest fire. Proceedings of the Royal Society B 283: 20161703. https://doi.org/10.1098/rspb. 2016.1703.

Ward, B., R. Cranfield, A. Wills, and V. Tunsell. 2017. Influence of fire-age mosaics on macrolichens and bryophytes in southwestern Australia. Journal of the Royal Society of Western Australia 100 (2): 32-45.

Watson, D.M. 2004. Comparative evaluation of new approaches to survey birds. Wildlife Research 31 (1): 1-11. https://doi.org/10.1071/WR03022.

Watson, S.J., R.S. Taylor, D.G. Nimmo, L.T. Kelly, M.F. Clarke, and A.F. Bennett. 2012a. The influence of unburnt patches and distance from refuges on postfire bird communities. Animal Conservation 15 (5): 499-507 https://doi.org/10. 1111/j.1469-1795.2012.00542.x.

Watson, S.J., R.S. Taylor, D.G. Nimmo, L.T. Kelly, A. Haslem, M.F. Clarke, and A.F. Bennett. 2012b. Effects of time since fire on birds: how informative are generalized fire response curves for conservation management? Ecological Applications 22 (2): 685-696. https://doi.org/ 10.1890/11-0850.1

Wintle, B.A., M.A. McCarthy, K.M. Parris, and M.A. Burgman. 2004. Precision and bias of methods for estimating point survey detection probabilities. Ecological Applications 14 (3): 703-712. https://doi.org/10. 1890/02-5166

Wittkuhn, R., and T. Hamilton. 2010. Using fire history data to map temporal sequences of fire return intervals and seasons. Fire Ecology 6: 97-114. https:// doi.org/10.4996/fireecology.0602097.

Woinarski, J.C.Z. 1999. Fire and Australian birds: a review. In: Australia's biodiversity: responses to fire, ed. A.M. Gill, A. York, and Woinarski JCZ, 55-180. Canberra: Environment Australia.

Wood, S.W., B.P. Murphy, and D.M. Bowman. 2011. Firescape ecology: how topography determines the contrasting distribution of fire and rain forest in the south-west of the Tasmanian Wilderness World Heritage Area. Journal of Biogeography 38 (9): 1807-1820. https://doi.org/10.1111/j. 1365-2699.2011.02524.x.

Wooller, R.D., and K.S. Brooker. 1980. The effects of controlled burning on some birds of the understorey in karri forest. Emu 80 (3): 165-166. https://doi.org/ 10.1071/MU9800165.

Wooller, R.D., and M.C. Calver. 1988. Changes in an assemblage of small birds in the understorey of dry sclerophyll forest in southwestern Australia after fire. Wildlife Research 15 (3): 331-338. https://doi.org/10.1071/WR9880331.

Zar, J.H. 1974. Biostatistical analysis. Englewood Cliffs: Prentice-Hall, Inc.

\section{Publisher's Note}

Springer Nature remains neutral with regard to jurisdictional claims in published maps and institutional affiliations.

\section{Submit your manuscript to a SpringerOpen ${ }^{\circ}$ journal and benefit from:}

- Convenient online submission

- Rigorous peer review

- Open access: articles freely available online

- High visibility within the field

- Retaining the copyright to your article

Submit your next manuscript at $\boldsymbol{\nabla}$ springeropen.com 